(c) 2020, The Authors. Published by FASS Inc. and Elsevier Inc. on behalf of the American Dairy Science Association ${ }^{\circledR}$. This is an open access article under the CC BY-NC-ND license (http://creativecommons.org/licenses/by-nc-nd/4.0/).

\title{
Comparison of microbial fermentation data from dual-flow continuous culture system and omasal sampling technique: A meta-analytical approach
}

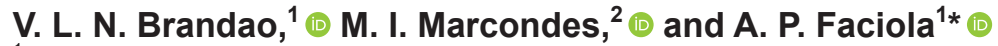 \\ ${ }^{1}$ Department of Animal Sciences, University of Florida, Gainesville 32611 \\ ${ }^{2}$ Department of Animal Science, Federal University of Viçosa, Viçosa, MG, Brazil, 36570900
}

\begin{abstract}
Although the omasal sampling technique (OST) has been successfully used to estimate ruminal fermentation and nutrient flow, alternatives to invasive animal trials should be pursued and evaluated. The objective of this study was to evaluate carbohydrate and $\mathrm{N}$ metabolisms using a meta-analytical approach to compare 2 methods: dual-flow continuous culture system (DFCCS) and OST. To be included, studies needed to report diet chemical composition and report at least 1 of the dependent variables of interest. A total of 155 articles were included, in which 97 used the DFCCS and 58 used the OST. The independent variables used were dietary nonfiber carbohydrate concentration, neutral detergent fiber (NDF) degradability, true crude protein (CP) degradability, and efficiency of microbial protein synthesis (EMPS). In addition, 12 dependent variables were used. Statistical analyses were performed using the Mixed procedure of SAS (SAS Institute Inc., Cary, $\mathrm{NC}$ ). A random coefficients model was used considering study as a random effect and including the possibility of covariance between the slope and the intercept. The effect of method (DFCCS or OST) was included and tested in the estimates of the intercept, linear, and quadratic effects of the independent variable. There was no method effect when NDF degradability was regressed with total volatile fatty acids concentration, true CP degradability, and EMPS. Molar proportions of acetate and propionate were quadratically associated with NDF degradability. When NDF degradability was regressed with acetate and propionate there was a method effect, differing only in the intercept $\left(\beta_{0}\right)$ estimate. True organic matter digestibility, bacterial N/ total $\mathrm{N}$, efficiency of $\mathrm{N}$ utilization, total volatile fatty acid concentration, and molar proportion of butyrate linearly increased as dietary nonfiber carbohydrate
\end{abstract}

Received June 13, 2019.

Accepted November 8, 2019.

*Corresponding author: afaciola@ufl.edu concentration increased, and none of these variables were affected by method. Concentration of ammonia $\mathrm{N}$ had a linear and positive association with true $\mathrm{CP}$ degradability. This was the only variable that had a method effect when regressed with true CP degradability, differing only in the estimate of the intercept $\left(\beta_{0}\right)$. As EMPS increased, efficiency of $\mathrm{N}$ utilization also increased, and it was affected by method. Overall, the majority of DFCCS responses were similar to OST. When a method effect was observed, it was mainly on the estimate of the intercept, demonstrating that the magnitude of these responses was different. However, the relationships between independent and dependent variables were similar across methods.

Key words: in vitro, nutrient flow, omasum, rumen

\section{INTRODUCTION}

Studies aiming to determine feed digestion, the effects of feed additives, or ruminal fermentation often require determination of ruminal fermentation end products and nutrient flow using cannulas fitted in the abomasum or duodenum (Ahvenjärvi et al., 2000). The omasal sampling technique (OST), described by Huhtanen et al. (1997) and modified by Ahvenjärvi et al. (2000), is a well-accepted technique for assessing ruminal fermentation and nutrient flow. It has been successfully used for estimating nutrient flows and ruminal metabolism of nitrogen (N; Reynal et al., 2003), carbohydrates (Owens et al., 2008), fatty acids (Sterk et al., 2012), and minerals (Tuori et al., 2008). Although this technique provides valuable results and is considered adequate for estimating ruminal fermentation and nutrient flow, it is laborious and expensive. Therefore, alternative techniques capable of accurately simulating ruminal fermentation are warranted.

The dual-flow continuous culture system (DFCCS), described by Hoover et al. (1976), aims to simulate the continuous differential flows of liquid and solids from the rumen. It provides a closer response to in vivo fermentation than do closed-vessel incubations (Hoover et al., 1976). The system involves a long-term fermenta- 
tion, with periods varying from $8 \mathrm{~d}$ (Calsamiglia et al., 2002 ) to $11 \mathrm{~d}$ (Dai et al., 2019). It has been used mainly to evaluate the effect of feedstuffs and additives on fermentation, digestion, nutrient flow, and $\mathrm{N}$ metabolism in dairy (Brandao et al., 2018) and beef (Amaral et al., 2016) diets. One of the most important advantages of the DFCCS compared with other in vitro systems is the continuous removal of fermentation end products, which reduces issues with accumulating fermentation products, such as VFA and ammonia $\left(\mathrm{NH}_{3}\right)$, that can potentially inhibit fermentation. Additionally, the system allows for intense sampling, determination of degradation rates, and testing of feed additives that are in early developmental stages and not yet produced on a large scale, under a constant DMI and passage rate.

However, studies quantitatively comparing ruminal fermentation data originating from DFCCS with those originating from OST are still scarce. Hristov et al. (2012) compared the variability of data from continuous culture systems with in vivo data; however, that study included a wide variety of in vitro systems and compared them with in vivo total-tract digestibility, which can be different when compared with ruminal digestibility. Therefore, we hypothesized that ruminal carbohydrate and $\mathrm{N}$ metabolism have similar responses to the independent variables used in this study when estimated using DFCCS and OST. The objective of this study was to summarize the literature and evaluate carbohydrate and $\mathrm{N}$ metabolism using a meta-analytical approach to compare 2 methods, DFCCS and OST.

\section{MATERIALS AND METHODS}

\section{Data Collection and Preparation}

A search for relevant articles was made using PubMed, Science Direct, and Google Scholar databases as well as individual journal databases, such as Journal of Dairy Science, Journal of Animal Science, Livestock, Animal Feed Science and Technology, and Animal from summer 2018 to spring 2019. Data were collected from peerreviewed articles published from 1985 to 2019, and 2 unpublished studies (DFCCS) from our research group were also included. The keywords used for the DFCCS data set were "dual-flow continuous culture system," "in vitro," "microbial fermentation," and different combinations of these words. The keywords used for the OST data set were "microbial fermentation," "nutrient flow," "omasal sampling," "omasum," "rumen," and "ruminal fermentation." In each article evaluated, including meta-analysis and review articles, the reference list was also searched for relevant titles. Only articles written in English were considered in the present study.
As a search criterion for both DFCCS and OST, the study under evaluation needed to report the chemical composition of the diet (at least dietary CP and NDF) and at least 1 of the dependent variables of interest (Table 1). We used as independent variables dietary NFC concentration, NDF degradability, true CP degradability, and EMPS; the descriptive statistics are presented in Table 1 and Supplemental Table S1 (https: //doi.org/10.3168/jds.2019-17107). The dependent and independent variables were selected with the aim of having a comprehensive set of fermentation responses related to ruminal $\mathrm{N}$ and carbohydrate metabolism. True CP degradability and EMPS were selected to represent $\mathrm{N}$ metabolism, and dietary NFC concentration and NDF degradability were used to represent carbohydrate metabolism. Therefore, to have a wider combination of variables used to develop the regressions, EMPS and degradability of NDF and true CP were used as independent and dependent variables.

To be included, the study needed to report individual treatment least squares means and standard error of the mean (SEM) or standard deviation. If the article did not report SEM but reported standard error of the means or standard deviation, then SEM was calculated according to Steel et al. (1997). We included only studies that performed omasal sampling through ruminal cannula, and no reticulum, abomasum, or duodenum sampling studies were included. Most of the DFCCS studies aimed to evaluate different feeds and additives. For the DFCCS data set, all studies used inoculum from dairy $(\mathrm{n}=368$ treatment means) or beef $(\mathrm{n}=$ 87 treatment means) cattle; therefore, studies using inocula from other ruminant species were not considered in the present study. This study considered only data from dual-flow continuous cultures system, and data from systems such as Rusitec or any other in vitro system were not included.

All studies using OST used changeover design, and out of 58 studies included, 5 used beef animals ( $\mathrm{n}=$ 13 treatment means) and 53 used dairy cows $(\mathrm{n}=182$ treatment means). After a thorough review of the studies under consideration, the data were entered in the database, and the last step was to verify each data entry. A total of 153 peer-reviewed published articles and 2 unpublished studies (using DFCCS from our research group) were included, containing 650 treatment means (455 DFCCS and 195 OST). The mean number of observations per dietary treatment was 4.4 and ranged from 2 to 9 . The complete list of studies included in this meta-analysis is presented in Supplemental File S1 (https://doi.org/10.3168/jds.2019-17107).

The solid passage rate for DSCCS ranged from 2 to $8 \% / \mathrm{h}$ and averaged $5 \% / \mathrm{h}$, whereas the liquid passage 
Table 1. Descriptive statistics of dependent (D) and independent (I) variables for the data set comparing microbial fermentation from dual-flow continuous culture system (DFCCS) and omasal sampling technique (OST) studies

\begin{tabular}{|c|c|c|}
\hline Item, $\%$ unless otherwise stated & DFCCS & OST \\
\hline \multicolumn{3}{|l|}{ NDF degradability $(\mathrm{D}, \mathrm{I})$} \\
\hline Mean & 49.59 & 47.09 \\
\hline SD & 16.47 & 13.70 \\
\hline $\mathrm{N}$ & 308 & 176 \\
\hline \multicolumn{3}{|l|}{ Dietary NFC concentration (I) } \\
\hline Mean & 33.48 & 44.41 \\
\hline SD & 14.64 & 4.83 \\
\hline $\mathrm{N}$ & 170 & 73 \\
\hline \multicolumn{3}{|l|}{ True CP degradability (D, I) } \\
\hline Mean & 59.60 & 64.93 \\
\hline SD & 16.54 & 9.50 \\
\hline $\mathrm{N}$ & 275 & 110 \\
\hline \multicolumn{3}{|l|}{ EMPS, ${ }^{1} \mathrm{~g} / \mathrm{kg}(\mathrm{D}, \mathrm{I})$} \\
\hline Mean & 28.18 & 28.79 \\
\hline SD & 10.40 & 7.98 \\
\hline $\mathrm{N}$ & 321 & 128 \\
\hline \multicolumn{3}{|l|}{$\mathrm{ENU}^{2}(\mathrm{D})$} \\
\hline Mean & 52.25 & 65.26 \\
\hline SD & 19.76 & 10.92 \\
\hline $\mathrm{N}$ & 317 & 136 \\
\hline \multicolumn{3}{|l|}{ True OM digestibility (D) } \\
\hline Mean & 57.51 & 66.46 \\
\hline SD & 11.77 & 8.08 \\
\hline $\mathrm{N}$ & 323 & 127 \\
\hline \multicolumn{3}{|l|}{$\mathrm{NH}_{3}-\mathrm{N},{ }^{3} \mathrm{mg} / \mathrm{dL}(\mathrm{D})$} \\
\hline Mean & 12.78 & 9.28 \\
\hline SD & 6.28 & 4.33 \\
\hline $\mathrm{N}$ & 355 & 174 \\
\hline \multicolumn{3}{|l|}{ Bacterial N/total N ${ }^{4}(\mathrm{D})$} \\
\hline Mean & 45.73 & 63.83 \\
\hline SD & 12.42 & 9.34 \\
\hline $\mathrm{N}$ & 256 & 98 \\
\hline \multicolumn{3}{|l|}{ NANMN/total N $N^{5}(\mathrm{D})$} \\
\hline Mean & 36.28 & 31.83 \\
\hline SD & 18.14 & 8.28 \\
\hline $\mathrm{N}$ & 256 & 98 \\
\hline \multicolumn{3}{|l|}{ Total VFA, mM (D) } \\
\hline Mean & 97.26 & 108.03 \\
\hline SD & 27.65 & 18.29 \\
\hline $\mathrm{N}$ & 395 & 176 \\
\hline \multicolumn{3}{|l|}{ Acetate (D) } \\
\hline Mean & 57.10 & 64.32 \\
\hline SD & 9.44 & 3.79 \\
\hline $\mathrm{N}$ & 395 & 176 \\
\hline \multicolumn{3}{|l|}{ Propionate (D) } \\
\hline Mean & 25.54 & 20.03 \\
\hline SD & 8.56 & 3.19 \\
\hline $\mathrm{N}$ & 395 & 176 \\
\hline \multicolumn{3}{|l|}{ Butyrate (D) } \\
\hline Mean & 11.72 & 11.77 \\
\hline SD & 4.39 & 1.76 \\
\hline $\mathrm{N}$ & 395 & 176 \\
\hline
\end{tabular}

${ }^{1}$ Efficiency of microbial protein synthesis ( $\mathrm{g}$ of microbial N/kg of truly digested $\mathrm{OM})$.

${ }^{2}$ Efficiency of nitrogen use, calculated according to Bach et al. (1999) for DFCCS and Brito et al. (2009) for OST.

${ }^{3}$ Ammonia nitrogen.

${ }^{4}$ Proportion of bacterial nitrogen over total nitrogen flow (omasal $\mathrm{N}$ flow for OST and effluent N flow for DFCCS), expressed as \%.

${ }^{5}$ Proportion of nonammonia nonmicrobial nitrogen over total nitrogen flow (omasal $\mathrm{N}$ flow for OST and effluent $\mathrm{N}$ flow for DFCCS), expressed as \%. rate ranged from 4 to $12.5 \% / \mathrm{h}$ and averaged $10 \% / \mathrm{h}$. Most experiments used artificial saliva, described by Weller and Pilgrim (1974), with addition of $0.4 \mathrm{~g}$ of urea/L to simulate $\mathrm{N}$ recycling. The average volume of the fermentation vessels was $1,209 \mathrm{~mL}$, with a minimum of $700 \mathrm{~mL}$ and a maximum of $1,830 \mathrm{~mL}(\mathrm{SD}=289)$.

Efficiency of microbial protein synthesis (EMPS) was calculated as grams of microbial $\mathrm{N}$ divided by kilograms of OM truly digested in the rumen. When individual VFA were reported as a concentration, molar proportion was calculated using total VFA concentration. Efficiency of N use (ENU) was calculated according to Bach et al. (1999) for DFCCS studies and expressed as grams of bacterial $\mathrm{N}$ per gram of $\mathrm{N}$ intake (Brito et al., 2009) for OST. The NFC concentration was used only when the study reported it. The studies determined microbial $\mathrm{N}$ flow using ${ }^{15} \mathrm{~N}$ or purine derivatives. To allow comparison of $\mathrm{N}$ metabolism data between DFCCS and OST, bacterial $\mathrm{N}$ and nonammonia nonmicrobial N (NANMN) were divided by the total $\mathrm{N}$ flow and multiplied by 100 . Therefore, these data are expressed in percentage of the total $\mathrm{N}$ flow.

\section{Data Cleaning and Model Derivation Procedure}

A preliminary graphical examination of the data was performed to identify the relationships between dependent and independent variables of interest as well as possible outliers (Sauvant et al., 2008). Data were weighted using the inverse of the standard error of the mean (Roman-Garcia et al., 2016) instead of the inverse of the squared standard error of the mean.

In this study, we used a data set of in vivo and in vitro studies; therefore, it was expected that the in vivo data set (OST) would have greater within-study variance than the in vitro data set (DFCCS). To prevent overweighting studies with very low SEM, SEM was truncated at one-fourth of the mean SEM among studies. The percentage of truncated SEM ranged from 6.19 to $15.63 \%$, and this process was done for the DFCCS and OST data sets separately. After trimming the SEM, the weight factor was normalized within method (DFCCS and OST). Briefly, the weight factor was calculated and then divided by the mean of the respective distribution, resulting in a distribution with mean equal to 1 . The normalization allowed equal weighting across methods, and dependent variables were weighted without the bias of the different methods used (RomanGarcia et al., 2016).

All statistical analyses were performed using the Mixed procedure of SAS (SAS Institute Inc., Cary, NC). A random coefficients model was used considering 
study as a random effect and including the possibility of covariance between the slope and the intercept. The covariance parameter was considered nonzero when $P$ $\leq 0.05$. Fifteen variance-covariance structures were tested, and the one that provided the smallest Akaike information criterion was used. Models were tested for linear and quadratic effects of the independent variable. Tables 2, 3, 4, and 5 present the coefficient of determination and residual mean squared error adjusted for the random effect of study, and the regression estimates are expressed as \pm SEM. Further details regarding mixed model analysis to integrate quantitative results can be found in St-Pierre (2001).

The effect of method (DFCCS or OST) was always included and tested in the initial model, and it was tested on the estimates of the intercept, linear, and quadratic effects of the independent variable. To derive the equations and generate the reduced models, a backward elimination procedure was used to remove parameters that had $P>0.05$. The initial model (complete) contained the intercept, linear, and quadratic terms of the independent variable and its interaction with the methods. Only 1 term was removed from the model at each step of the backward elimination; terms were sequentially removed starting with the greatest order. If a term with greater order was significant (i.e., quadratic), then the linear term was maintained in the model regardless of whether it was significant. Data from beef and dairy animals were included to provide a wider range of fermentation responses. To account for their different fermentation patterns, the effect of dairy or beef animal was included as a random effect in the model. Significance levels to fit the model assumed for fixed and random effects were $P \leq 0.05$. The effect of method was tested in NDF degradability, true CP degradability, and EMPS, and it was not significant for any of them $(P>0.05)$. It should be noted that this study was not intended to generate prediction models; instead, our objective was to understand and critically evaluate the functional form of the DFCCS fermentation responses compared with OST.

\section{RESULTS}

\section{Independent Variables: NDF Degradability and Dietary NFC Concentration}

Regressions using NDF degradability as an independent variable are presented in Table 2. True OM digestibility was quadratically associated with NDF degradability and was affected by method (Table 2). Only the estimates of intercept $\left(\boldsymbol{\beta}_{0}\right)$ were different, in which DFCCS had lower $\beta_{0}$ than OST (46.4\% and $56.2 \%$, respectively). True CP degradability had a quadratic association with NDF degradability. Method did not influence true CP degradability.

Concentration of $\mathrm{NH}_{3}-\mathrm{N}$ linearly increased as NDF degradability increased, and it had a method effect (Figure 1A). This was the only variable that had the same estimate of $\beta_{0}(3.6 \mathrm{mg} / \mathrm{dL})$ but different slope $(0.15$ and $0.07 \mathrm{mg} / \mathrm{dL}$ for DFCCS and OST, respectively). Bacterial N/total N was not associated with NDF degradability and had a method effect on the estimate of $\beta_{0}$, in which the study-corrected mean was $44.4 \%$ for DFCCS and $64.1 \%$ for OST. The NANMN/total N linearly decreased as NDF degradability increased and had a method effect. The DFCCS had greater $\beta_{0}$ and smaller slope $\left(\boldsymbol{\beta}_{1}\right)$ than OST. The ENU was not associated with NDF degradability. The study-corrected mean of ENU was $55.4 \%$ for DFCCS and $65.2 \%$ for OST; therefore, ENU was 9.8 percentage points greater in OST than in DFCCS.

Total VFA concentration was positively and quadratically associated with NDF degradability (Table 2). Total VFA concentration was not affected by method. Molar proportions of acetate (Figure 2A) and propionate (Figure 2B) were quadratically related to NDF degradability and were affected by method, differing only in the intercepts. Acetate was positively associated with NDF degradability, and propionate was negatively associated with NDF degradability. Molar proportion of acetate had a greater intercept in studies using OST $(52.7 \mathrm{~mol} / 100 \mathrm{~mol})$ than in studies using DFCCS (47.0 $\mathrm{mol} / 100 \mathrm{~mol}$ ). The opposite response was observed for molar proportion of propionate, in which the intercept was lower for OST studies $(33.9 \mathrm{~mol} / 100 \mathrm{~mol})$ than for DFCCS studies $(38.3 \mathrm{~mol} / 100 \mathrm{~mol})$. The NDF degradability was not associated with molar proportion of butyrate and did not have a method effect.

The regressions developed using dietary NFC concentration as an independent variable are presented in Table 3. As dietary NFC concentration increased, NDF degradability linearly decreased and was not affected by method. True OM digestibility and dietary NFC concentration were linearly and positively associated, and method did not affect this association. True CP degradability was quadratically associated with dietary NFC concentration, with a minimum point at $42 \%$ NFC, and it was not affected by method.

The $\mathrm{NH}_{3}-\mathrm{N}$ concentration linearly decreased as dietary NFC concentration increased and was not affected by method (Table 3). Bacterial N/total $\mathrm{N}$ had a linear and positive association with NFC concentration and was not affected by method. The NANMN/total N and EMPS were not affected by dietary NFC concentration or method, and their study-corrected means were 35.2 
Brandao et al.: RUMINAL FERMENTATION AND NUTRIENT FLOW

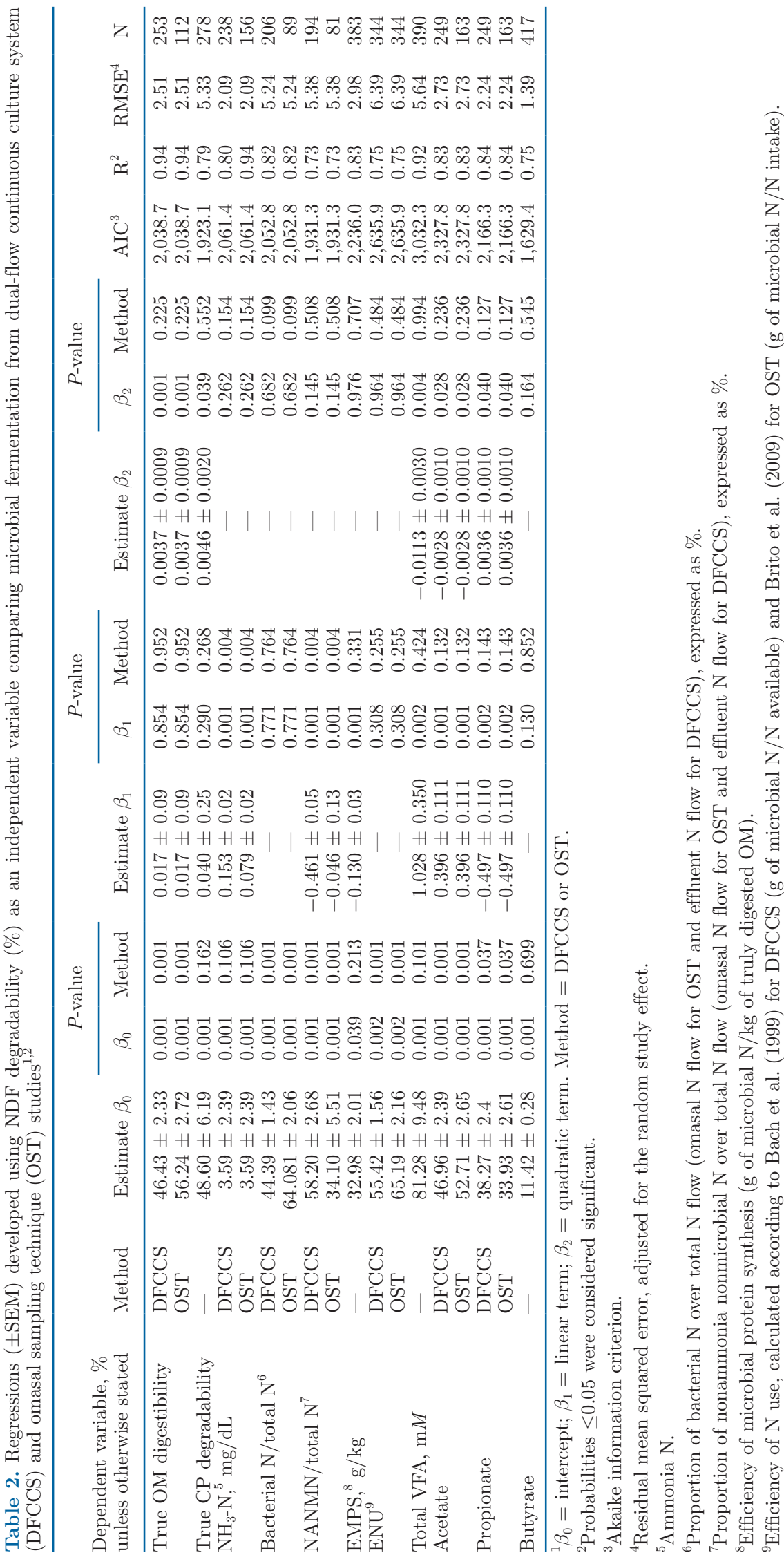




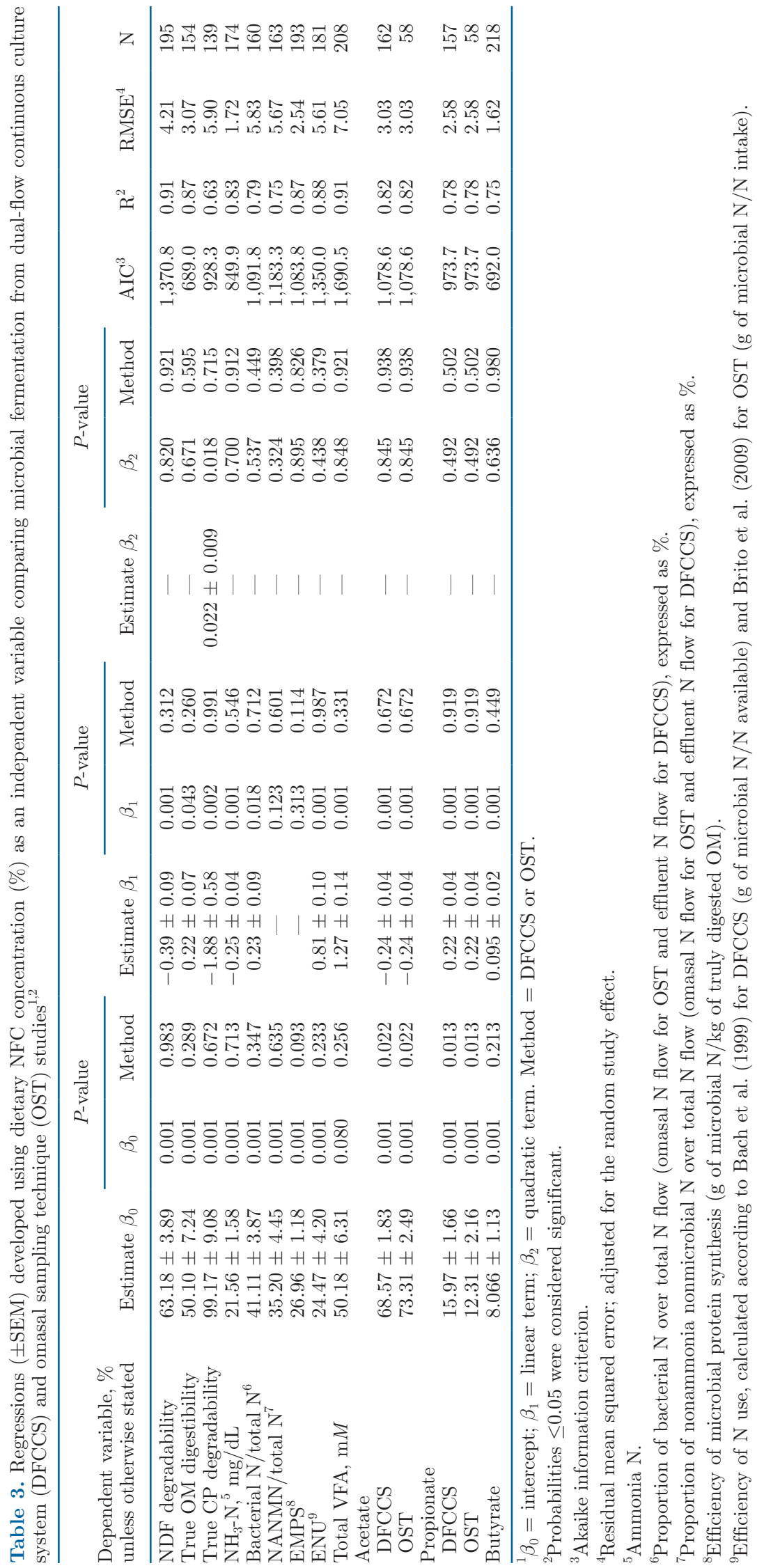




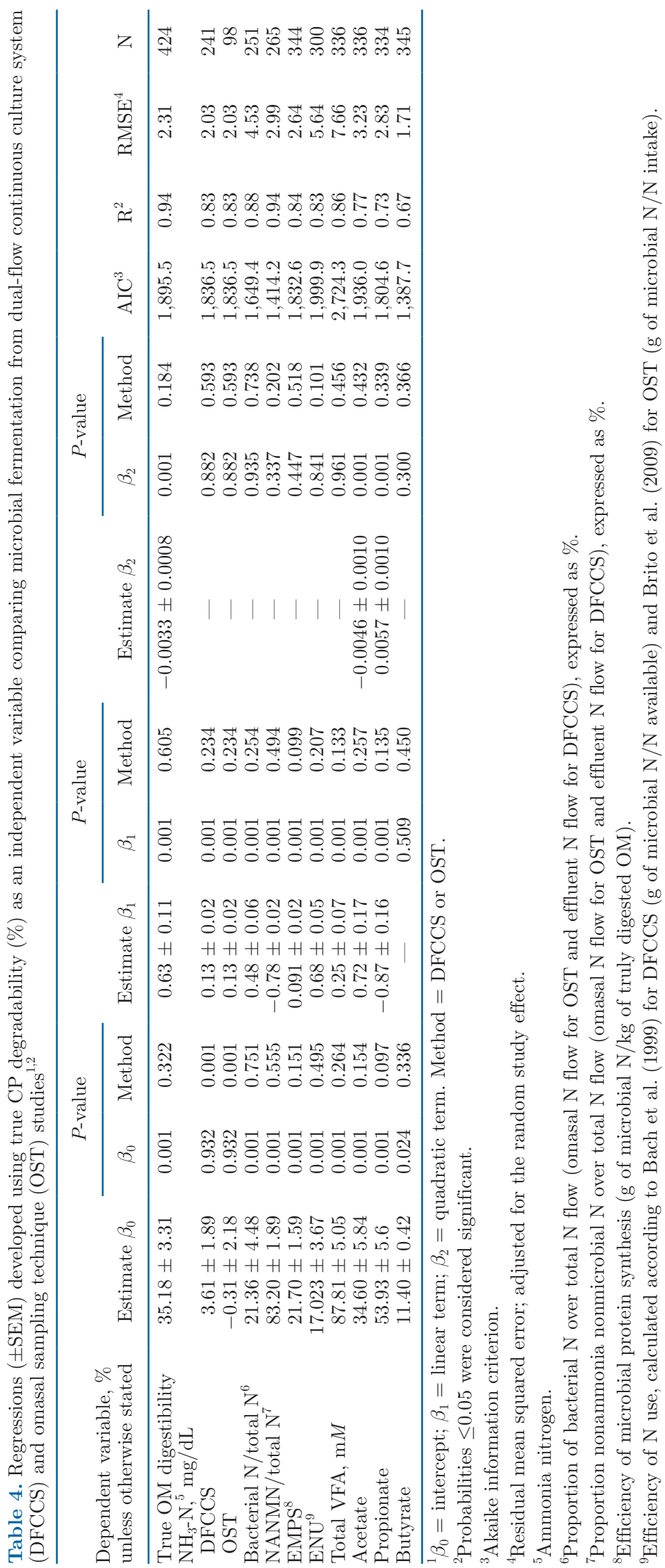




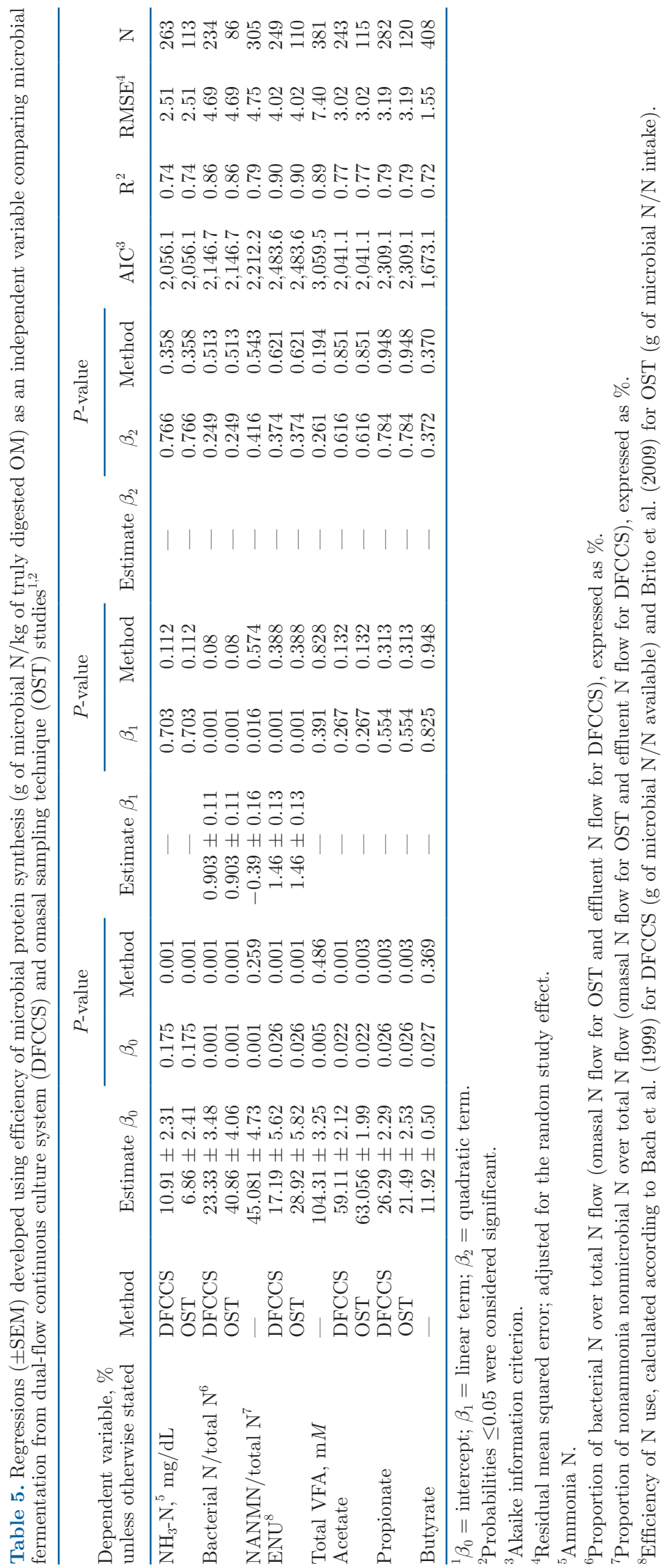



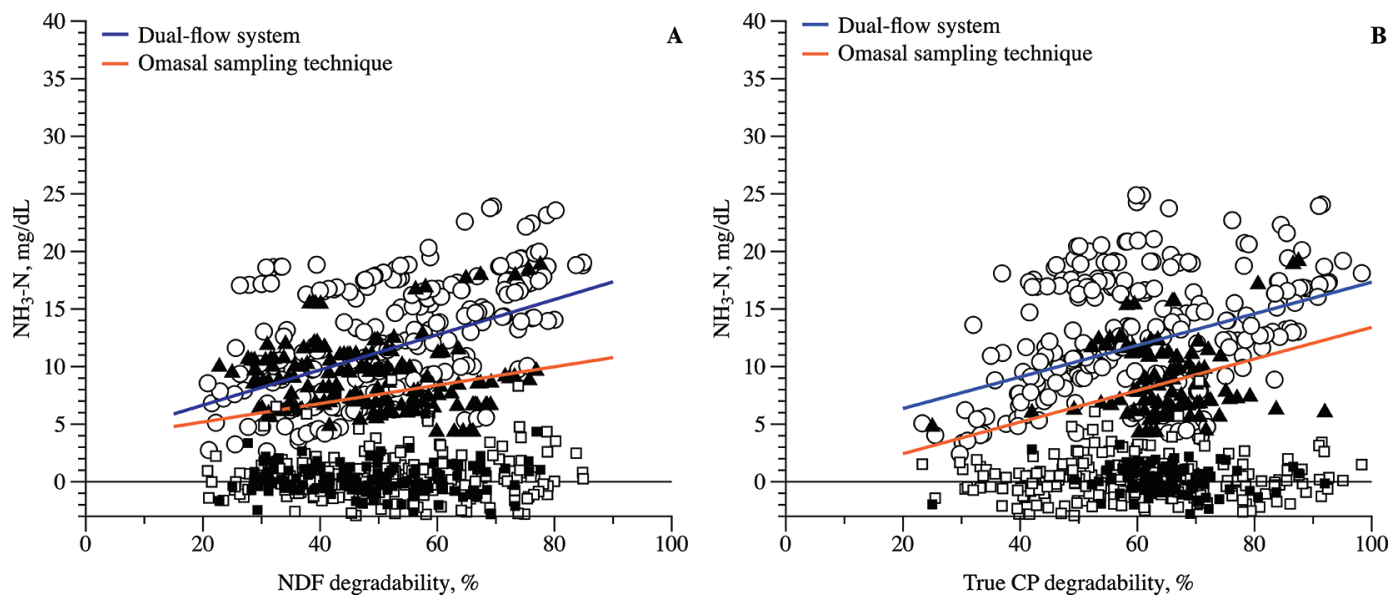

Figure 1. Adjusted concentration of ammonia $\left(\mathrm{NH}_{3}\right)$ regressed with NDF degradability $(\mathrm{A})$ and true CP degradability (B). Data were obtained from studies using dual-flow continuous culture $(\bigcirc)$ and their residuals $(\square)$ and from omasal sampling technique $(\boldsymbol{\Delta})$ and its residuals

(ם). Residuals (observed minus predicted) are represented in the x-axis 0-line.

and $27.0 \%$, respectively. The ENU and dietary NFC concentration had a linear and positive association and were not affected by method.

Total VFA concentration, acetate, propionate, and butyrate were linearly associated with NFC concentration (Table 3). Total VFA concentration was not affected by method. Molar proportion of acetate (Figure 2C) was negatively associated with dietary NFC concentration and propionate (Figure 2D) was positively associated with dietary NFC concentration, and both had a method effect. The method affected only the estimate of $\beta_{0}$, in which OST studies had a greater estimate of $\beta_{0}$ for acetate $(73.3 \mathrm{~mol} / 100 \mathrm{~mol})$ and a lower estimate for propionate $(12.3 \mathrm{~mol} / 100 \mathrm{~mol})$. Molar proportion of butyrate linearly increased as dietary NFC concentration increased and was not affected by method.

\section{Independent Variables: CP Degradability and EMPS}

The regressions developed using true CP degradability as an independent variable are presented in Table 4. Concentration of $\mathrm{NH}_{3}-\mathrm{N}$ was linearly and positively associated with true CP degradability (Figure 3B). This was the only dependent variable with a method effect when regressed with true $\mathrm{CP}$ degradability, differing only in the estimate of $\beta_{0}$. Studies using OST had a lower estimate of $\beta_{0}(-0.3 \mathrm{mg} / \mathrm{dL})$ than did those using DFCCS (3.6 mg/dL); however, they had the same estimate of $\beta_{1}$.

Bacterial N/total N (Figure 3A) was linearly associated with true CP degradability and was not affected by method (Table 4). The NANMN/total N linearly decreased as true CP degradability increased and was not affected by method (Figure 3B). The EMPS (Figure 3C), ENU (Figure 3D), and total VFA were linearly and positively associated with true CP degradability, and none of these variables were affected by method. Molar proportion of acetate quadratically increased as true CP degradability increased (Figure 2E), and molar proportion of propionate quadratically decreased (Figure $2 \mathrm{~F}$ ) as true $\mathrm{CP}$ degradability increased. Acetate had the maximum point at $78 \%$ of true CP degradability, and propionate had the minimum point at $76 \%$ of true CP degradability. Molar proportions of acetate, propionate, and butyrate were not affected by method.

Regressions developed using EMPS as an independent variable are presented in Table 5 . Concentration of $\mathrm{NH}_{3}-\mathrm{N}$ was not associated with EMPS. The studycorrected mean value for DFCCS was $10.9 \mathrm{mg} / \mathrm{dL}$ and for OST was $6.7 \mathrm{mg} / \mathrm{dL}$. Bacterial $\mathrm{N} /$ total $\mathrm{N}$ had a linear and positive association with EMPS. Method affected only the estimate of $\beta_{0}$, and OST had greater bacterial $\mathrm{N} /$ total $\mathrm{N}$ than DFCCS.

The NANMN/total N was linearly and negatively associated with EMPS (Figure 3E). As EMPS increased, ENU linearly increased (Figure 3F) and had an effect of method on the estimate of the intercept (Table 5). Total VFA, acetate, propionate, and butyrate were not associated with EMPS. Total concentration of VFA was not affected by method, and the study-corrected mean value was $104.3 \mathrm{~m} M$. Molar proportions of acetate and propionate were affected by method. The study-corrected mean for acetate was 59.1 and $63.1 \mathrm{~mol} / 100 \mathrm{~mol}$ in DFCCS and OST, respectively, and the study-corrected mean for propionate was 26.3 and $21.5 \mathrm{~mol} / 100 \mathrm{~mol}$ in DFCCS and OST studies, respectively. 

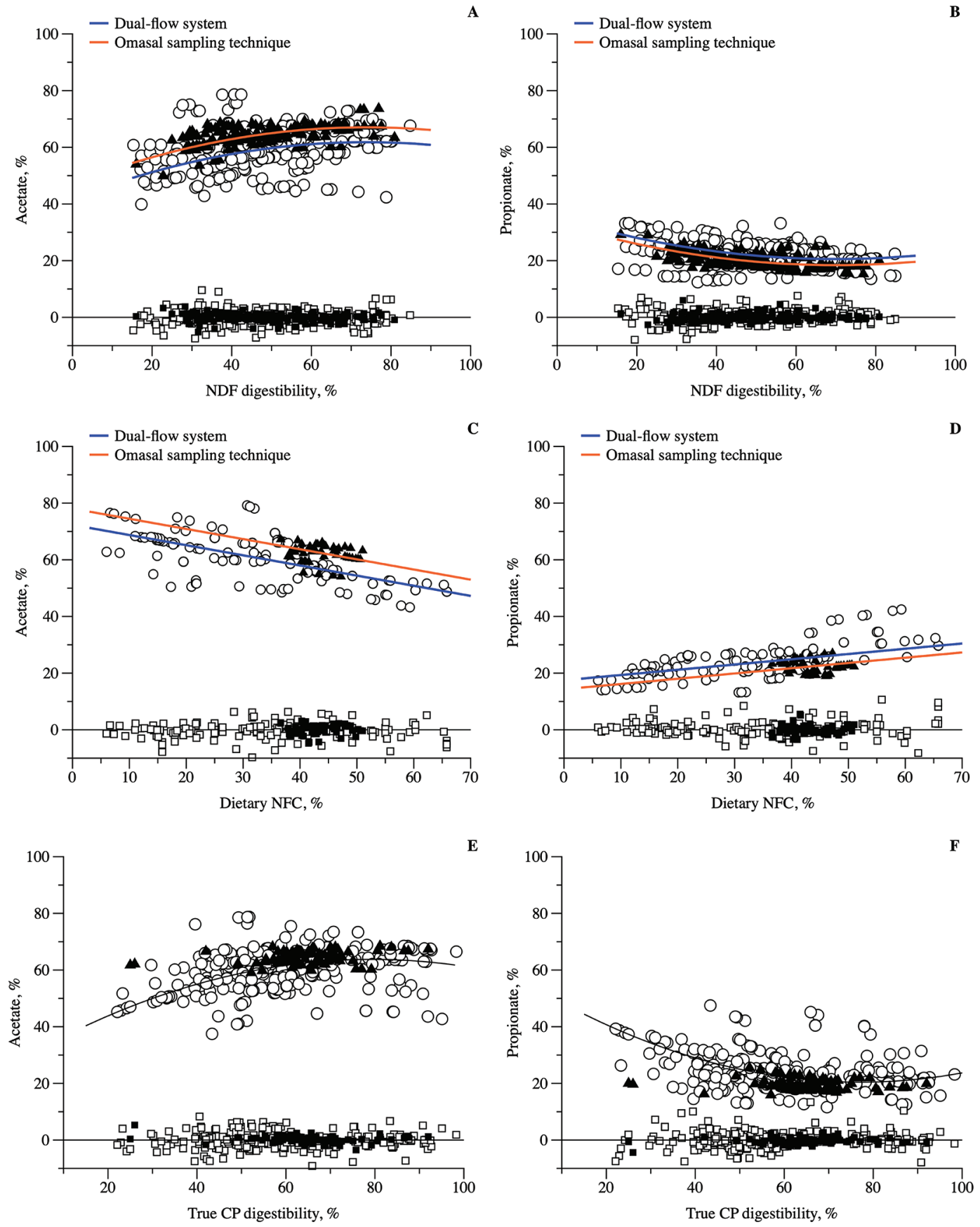

Figure 2. Adjusted molar ruminal proportion of acetate and propionate regressed with NDF degradability (A and B), regressed with dietary NFC concentration ( $\mathrm{C}$ and $\mathrm{D}$ ), and regressed with true $\mathrm{CP}$ degradability (E and F). Data were obtained from studies using dual-flow continuous culture $(\bigcirc)$ and their residuals $(\square)$ and from omasal sampling technique $(\boldsymbol{\Lambda})$ and its residuals $(\boldsymbol{\square})$. Residuals (observed minus predicted) are represented in the $\mathrm{x}$-axis 0 -line.

\section{DISCUSSION}

\section{Carbohydrates}

True OM digestibility was positively associated with the 2 carbohydrate independent variables used in the present study: NDF degradability (quadratically) and NFC concentration (linearly; Table 2). Changes in ruminal NDF degradability directly reflect on true ruminal OM digestibility considering that the rumen is the main site of fiber digestion (Broderick et al., 2010). Dietary NFC concentration was positively associated 
with true $\mathrm{OM}$ digestibility, possibly due to its high ruminal fermentability. In a study including 87 studies from beef and dairy cattle and a wide variety of starch sources, Offner and Sauvant (2004) reported ruminal starch degradability of $71.0 \%$. Therefore, increases in dietary NFC concentration can positively affect true OM digestibility by providing a greater amount of highly fermentable carbohydrates.

The NDF degradability was used as an independent variable in Table 2, and it was used as a dependent
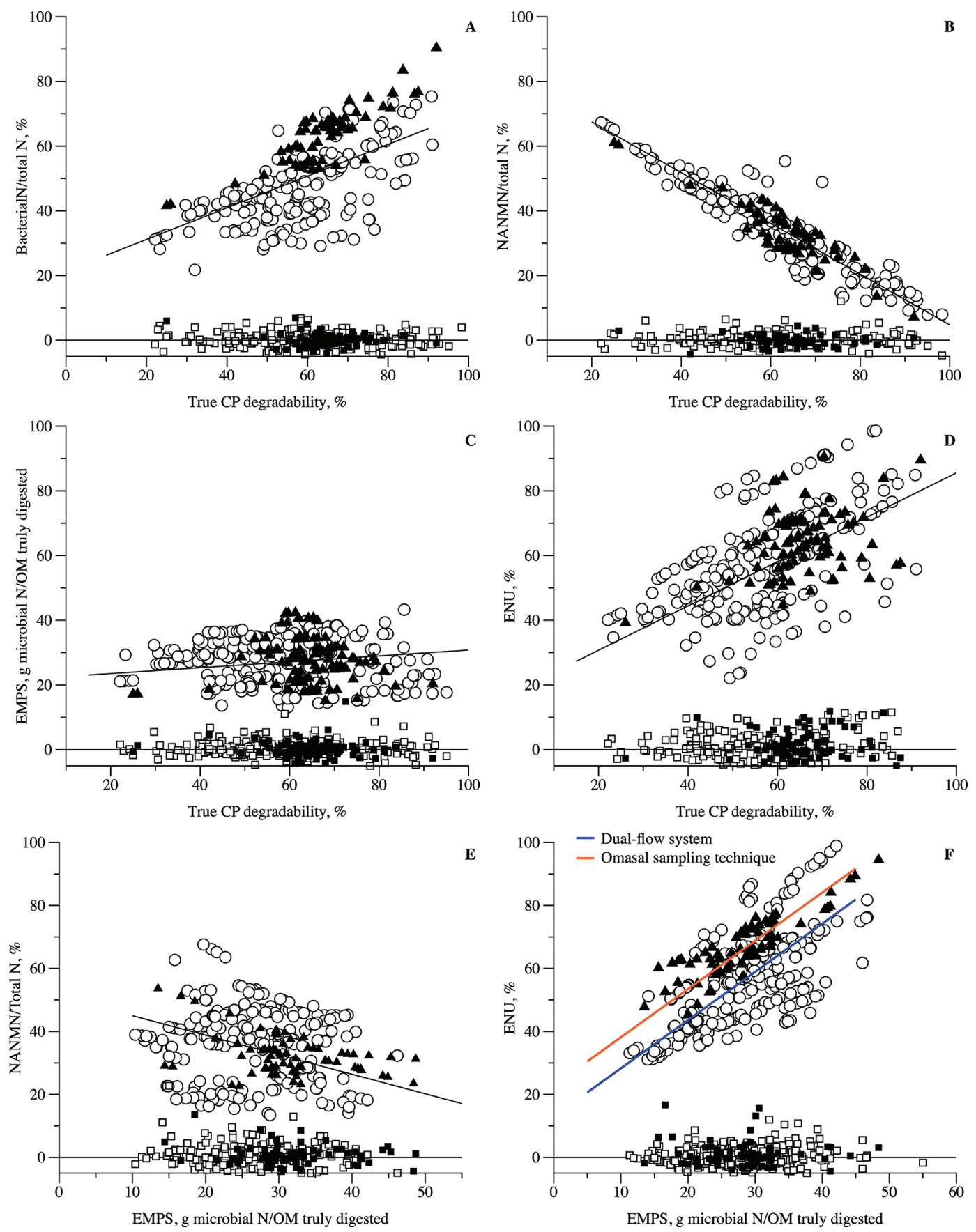

Figure 3. Adjusted proportion of bacterial N (A) and nonammonia nonmicrobial N (NANMN; B) from total N flow, efficiency of microbial protein synthesis (EMPS; C), and efficiency of N use (ENU; D) regressed with true CP degradability. Adjusted proportion of NANMN (E) and ENU (F) regressed with EMPS. Data were obtained from studies using dual-flow continuous culture (O) and their residuals $(\square)$ and from omasal sampling technique $(\boldsymbol{\Lambda})$ and its residuals $(\mathbf{\square})$. Residuals (observed minus predicted) are represented in the x-axis 0-line. 
variable and regressed against dietary NFC concentration in Table 3. Typically, dietary NFC concentration increases at the expense of NDF, which results in a diet with lower fiber. In in vivo studies, the association of highly fermentable carbohydrates with lower dietary $\mathrm{NDF}$ results in a decrease in ruminal $\mathrm{pH}$ (Oba and Allen, 2003), which can affect fiber degradability. In DFCCS studies, $\mathrm{pH}$ is commonly controlled, suggesting that this negative association between NDF degradability and dietary NFC concentration is more sensitive to changes in substrate rather than only $\mathrm{pH}$.

Concentration of VFA in the rumen is affected by several factors, including but not limited to rate and extent of $\mathrm{OM}$ digestion. Highly digestible feeds are degraded in the rumen, producing VFA as an end product (Russell et al., 1992). Therefore, in agreement with the digestibility responses, total VFA concentration increased in response to increases in NFC concentration and NDF degradability (Tables 3 and 2, respectively). Total VFA concentration was not affected by method when regressed with all independent variables used, suggesting that estimates of VFA concentration might be close when made using DFCCS and OST. The rate of VFA absorption by the ruminal wall can affect ruminal total VFA concentration (Hall et al., 2015); however, in DFCCS, there is no absorption and VFA are removed through digesta outflow. We speculate that the digesta outflow rate in DFCCS is similar to the rumen hall absorption rate and the rate of VFA that are washed out from rumen via passage rate, which may explain the lack of method effect on the estimates of VFA concentration.

Chemical structure of the protein and its interaction with carbohydrates are important factors that determine ruminal CP degradability (NRC, 2001). Part of the total CP in feeds is bound to the plant cell wall, and it can be slowly degraded or be of low biological availability (Sniffen et al., 1992). As plants mature, the contribution of this slowly degraded CP portion increases. Therefore, if a large portion of $\mathrm{CP}$ is bound to the plant cell wall (primarily lignin), CP degradability tends to decrease due to reduced microbial access to nitrogenous compounds. This may explain the observed positive association between true $\mathrm{CP}$ degradability and NDF degradability (Table 2). Therefore, this positive association between degradabilities of true $\mathrm{CP}$ and NDF is likely a reflection of a more digestible feed.

Molar proportion of butyrate usually does not change often and ranges from 10 to 20\% (Bergman, 1990). In the present study, molar proportion of butyrate only responded to increments in dietary NFC concentration and had an overall study-corrected mean of $11.7 \%$, which is within the literature values. Considering that
NFC encompasses starch and sugars, it has been shown in continuous culture (Vallimont et al., 2004) and in vivo (DeFrain et al., 2004) that increasing dietary NFC concentration might result in greater butyrate concentration. Additionally, the positive and linear response of butyrate to dietary NFC concentration is possibly associated with accumulation of lactate in the rumen due to the presence of large amounts of rapidly fermentable carbohydrates (Nagaraja and Titgemeyer, 2007). Increased concentration of butyrate has been observed in animals fed high-grain diets (Coe et al., 1999). Ruminal lactate metabolism can generate acetate, propionate, butyrate, and to a lesser extent caproate and valerate (Marounek et al., 1989). However, the primary end product varies depending on ruminal $\mathrm{pH}$ (Satter and Esdale, 1968): when the $\mathrm{pH}$ is acidic, butyrate is preferably produced from acetate (Satter and Esdale, 1968). It has been proposed that butyrate can be produced from acetate utilizing the 2 hydrogen atoms released by the oxidation of lactate to pyruvate; therefore, butyrate formation might work as a hydrogen sink (Esdale et al., 1968).

\section{N Metabolism}

Carbohydrates, primarily rapidly fermentable carbohydrates such as NFC, determine the energy available for microbial growth and microbial $\mathrm{N}$ yield (Schwab et al., 2006). Therefore, the negative and linear response of $\mathrm{NH}_{3}-\mathrm{N}$ to increases in dietary NFC concentration (Table 3) is likely associated with greater microbial protein synthesis, which results in lower $\mathrm{NH}_{3}-\mathrm{N}$ accumulation (Oba and Allen, 2003; Schwab et al., 2006). Indeed, bacterial $\mathrm{N} /$ total $\mathrm{N}$ increased as dietary NFC concentration increased (Table 3), whereas NANMN/ total $\mathrm{N}$ was not associated with dietary NFC concentration. Interestingly, even though bacterial N/total N increased in response to NFC, EMPS was not associated with dietary NFC concentration. This suggests that yield of microbial protein increased due to abundance of substrate; however, the efficiency of converting truly digested $\mathrm{OM}$ into microbial $\mathrm{N}$ did not change. Bach et al. (2005) observed that bacterial $\mathrm{N}$ flow decreased as ruminal $\mathrm{pH}$ increased; however, EMPS was not associated with rumen $\mathrm{pH}$, which commonly respond to changes in carbohydrate fermentability. Additionally, ruminal $\mathrm{NH}_{3}-\mathrm{N}$ was insensitive to EMPS (Table 5), and a similar response has been reported by Bach et al. (2005) and Oba and Allen (2003). When true CP degradability was used as a dependent variable (Tables 2 and 3), it was not affected by method, demonstrating that the estimate of true CP degradability using DFCCS is similar to that using OST. 
Passage rate and digestion are competitive processes (Mertens, 1977) that affect ruminal fermentation. It is interesting to note that in DFCCS studies the passage rate is constant, whereas in OST studies it is variable and largely affected by intake and diet characteristics. Furthermore, it is possible that the continuous removal of fermentation end products reduces the issue with accumulation of products that can inhibit fermentation, resulting in responses similar to those observed in vivo.

\section{Dependent Variables Affected by Method}

When ENU was regressed with EMPS (Figure 3F), we observed a linear and positive association. However, when Bach et al. (2005) regressed these 2 variables, they reported a quadratic response, with a maximum point at $29 \mathrm{~g}$ of microbial $\mathrm{N} / \mathrm{kg}$ of fermented $\mathrm{OM}$ and $69 \mathrm{~g}$ of microbial N/100 g of rumen available N. This different response may be attribute to several factors. First, Bach et al. (2005) included a smaller number of observations $(\mathrm{n}=136)$ than the present study. Second, they had no studies with ENU $<40 \%$; however, even without points below $40 \%$ ENU, we would likely still have a linear association. Third, it is possible that some studies used in Bach et al. (2005) were also used in the present study; however, we have additional data from 2005 to 2019. Fourth, we included DFCCS and OST data in our analysis, whereas Bach et al. (2005) used only DFCCS. Finally, our equation has lower residual mean squared error (4.63 vs. 6.54), wider range of ENU, and greater coefficient of determination, suggesting a better fit of the model. Therefore, it is possible that our result is more robust than that reported by Bach et al. (2005).

In NRC (2001), EMPS was regressed against apparent ruminal $\mathrm{N}$ balance and had a negative linear relationship, with EMPS ranging approximately from 12 to $54 \mathrm{~g}$ of microbial $\mathrm{N} / \mathrm{kg}$ of fermented OM, which is similar to our EMPS range (Figure 3F). This demonstrates that microbial use of $\mathrm{N}$ and energy utilization become uncoupled if available ruminal $\mathrm{N}$ is relativity high and fermented OM is low. This result supports the linear association observed in the present study when regressing ENU against EMPS. At low ENU, EMPS is also low, likely due to the low energy available. Also, if an abundance of energy is available and $\mathrm{N}$ is not limiting, the greater the energy available, the greater the efficiency of converting $\mathrm{N}$ into microbial $\mathrm{N}$. The NRC (2001) assumes a fixed ENU of $85 \%$ and EMPS of approximately $21 \mathrm{~g}$ of microbial $\mathrm{N} / \mathrm{kg}$ of fermented OM. In our data set when ENU is $85 \%$, the projected EMPS is approximately 46 and $38 \mathrm{~g}$ of microbial $\mathrm{N} / \mathrm{kg}$ of fermented OM for DFCCS and OST, respectively.
Even though NRC (2001) recommends a fixed EMPS, it acknowledged that EMPS is responsive to dietary manipulations. Therefore, EMPS provides valuable insights on microbial energy use, and ENU is an indicator of $\mathrm{N}$ use. These 2 variables are complementary, and their use in association is generally recommended.

Molar proportion of acetate reached the maximum point at approximately $70 \%$ NDF degradability, and molar proportion of propionate reached the minimum point at approximately 69\% NDF degradability (Table 2), suggesting that the NDF degradability point that maximizes acetate is similar to the point that minimizes propionate (Figure 2A and $\mathrm{B}$ ). Because the method has an effect only on the estimate of $\beta_{0}$, the NDF degradability point that maximizes acetate and minimizes propionate is the same for both DFCCS and OST. Similarly, when molar proportions of propionate and acetate were regressed with dietary NFC concentration and EMPS (Tables 3 and 5), OST had a greater estimate of $\beta_{0}$ for acetate and lower propionate than did DFCCS.

Acetate was consistently lower and propionate was greater in DFCCS. Method affected the $\beta_{0}$ estimate of acetate and propionate in 6 out of the 8 regressions reported in Tables 2 to 5 . This shift in the intercept demonstrates that even though the magnitude of the response was different, the functional relationship was maintained between methods. There is some evidence in the literature that molar proportion of acetate is lower in DFCCS due to a decrease in fibrolytic population (Mansfield et al., 1995). Our results are in agreement with Hristov et al. (2012), who also observed lower molar proportion of acetate in continuous culture studies compared with in vivo studies.

Concentration of $\mathrm{NH}_{3}-\mathrm{N}$ was related linearly and positively with true CP and NDF degradability (Figure 1). The study-corrected means of $\mathrm{NH}_{3}-\mathrm{N}$ concentration were 12.2 and $8.4 \mathrm{mg} / \mathrm{dL}$ in DFCCS and OST, respectively, resulting in a $30 \%$ difference. Increments in NDF degradability resulted in greater $\mathrm{NH}_{3}-\mathrm{N}$ accumulation in DFFCS; this was the only variable with nonsignificant $\beta_{0}$ but significant linear term $\left(\beta_{1}\right)$ between methods (Table 2 ). This result can be partially explained by the fact that in DFCCS, no $\mathrm{NH}_{3}-\mathrm{N}$ absorption occurs through the wall and the only way out of the system is through overflow, whereas in vivo, $\mathrm{NH}_{3}-\mathrm{N}$ is absorbed through the portal-drained viscera, extracted by the liver, and converted to urea (Lapierre and Lobley, 2001). Urea is then excreted in the urine or recycled via saliva or other sections of the gastrointestinal tract (Gozho et al., 2008).

In an experiment studying the effect of increasing $\mathrm{N}$ intake on urea kinetics and recycling, Marini and 
Van Amburgh (2003), using Holstein heifers, reported $\mathrm{N}$ recycling ranging from $29 \%$ in high-N diets to $83 \%$ in a low-N diet. Additionally, Lapierre and Lobley (2001) reported that in cattle, an average of 30 to $40 \%$ of the $\mathrm{N}$ intake is recycled and returned to the gut as urea. In DFCCS studies, urea is commonly added in the artificial saliva aiming to simulate $\mathrm{N}$ recycling (Hannah et al., 1986). This practice is important when low-CP diets are used, and similar to in vivo, the contribution of urea recycling is important to ensure microbial growth. Satter and Slyter (1974), using continuous culture fermenters, suggested a minimum of $5 \mathrm{mg} / \mathrm{dL}$ of ruminal $\mathrm{NH}_{3}-\mathrm{N}$ to ensure microbial growth. Therefore, in experiments in which the diet provides enough $\mathrm{N}$, the addition of urea might result in a greater $\mathrm{NH}_{3}-\mathrm{N}$ input in the system than the microbial population is capable of converting into microbial N.

In our data set, dietary CP averaged $16.8 \%$ for DF$\mathrm{CCS}($ minimum $=4.0$, maximum $=28.7, \mathrm{SD}=3.2)$ and $16.3 \%$ for OST $($ minimum $=9.9$, maximum $=23.8$, $\mathrm{SD}=2.1$ ). Considering a hypothetical scenario of $0.4 \mathrm{~g}$ of urea/L added via saliva to the fermenters, a passage rate of $10 \% / \mathrm{h}$ for liquids and $5 \% / \mathrm{h}$ for solids, and a fermenter volume of $1,830 \mathrm{~mL}$, a total of $1.728 \mathrm{~g}$ of urea $(0.795 \mathrm{~g}$ of $\mathrm{N})$ is added to each fermenter daily. Therefore, if the experimental diet was formulated containing $16.8 \% \mathrm{CP}$, the urea input by saliva represents approximately $28 \%$ of additional $\mathrm{N}$ input, which represents $28 \%$ of $\mathrm{N}$ recycling. This $\mathrm{N}$ recycling value is in agreement with in vivo data (Lapierre and Lobley, 2001; Marini and Van Amburgh, 2003).

In vivo, the ruminal $\mathrm{N}$ balance is represented by the $\mathrm{N}$ input coming from diet, rumen wall, saliva, and the endogenous fraction and the output from the rumen wall and flow to omasum. In DFCCS, the only way out of $\mathrm{N}$ is by overflow. Therefore, we speculate that the $\mathrm{N}$ added in the artificial saliva used in DFCCS should represent the balance ( $\mathrm{N}$ recycling minus $\mathrm{N}$ output) instead of only the $\mathrm{N}$ recycling. The NRC (2001) assumes that approximately $15.2 \%$ of RDP is lost in the rumen at an apparent $\mathrm{N}$ balance of zero. Considering $\mathrm{N}$ recycling of approximately $28 \%$, the balance would be approximately $13 \%$. We speculate that by reducing urea in the artificial saliva to approximately 0.19 $\mathrm{g} / \mathrm{L}$, the ruminal $\mathrm{NH}_{3}-\mathrm{N}$ values obtained using DFCCS might be more closely related to OST. We also hypothesize that considering that $\mathrm{N}$ recycling is regulated by $\mathrm{N}$ intake (Marini and Van Amburgh, 2003), the amount of urea added in the artificial saliva needs to be adjusted according to factors such as CP level and extent of ruminal protein degradation. Depending on the diet fed to the fermenter, it is possible that this addition of $0.4 \mathrm{~g}$ of urea/L exceeds the ruminal microbial ability to metabolize $\mathrm{NH}_{3}$, resulting in accumulation, which might explain the difference in $\mathrm{NH}_{3}-\mathrm{N}$ observed between the 2 methods. Therefore, studies adjusting the amount of urea added in the artificial saliva in DFCCS are warranted.

In summary, out of 41 regressions developed in the present study, method affected only 14 estimates of $\beta_{0}$ and 2 estimates of linear term $\left(\beta_{1}\right)$. Because the majority of method effect was observed only in the estimate of the intercept, it is likely that treatment effects observed in DFCCS are maintained when tested in vivo; however, the magnitude of the response may be different. In those cases, results need to be interpreted cautiously when extrapolating DFCCS data to in vivo, especially regarding $\mathrm{NH}_{3}-\mathrm{N}$ concentration. Our results indicate that DFCCS provides valuable estimates of ruminal fermentation and that, overall, the functional responses observed in DFCCS studies are similar to those observed in OST studies.

\section{CONCLUSIONS}

This meta-analysis was performed to compare ruminal fermentation responses in vitro using the continuous cultures system with responses obtained from in vivo studies using OST. Overall, method affected OM digestibility and molar proportion of acetate and propionate; however, the difference was observed only in the estimates of intercept. Even though we observed a method effect for molar proportion of acetate and propionate, total VFA concentration was not affected by method. Method only affected NANMN/total N when regressed with NDF degradability, whereas bacterial $\mathrm{N} /$ total $\mathrm{N}$ was affected by method when regressed with NDF degradability and EMPS. Furthermore, true CP degradability and EMPS responses were not affected by method. Concentration of $\mathrm{NH}_{3}-\mathrm{N}$ was the only variable that had a method effect on estimate of intercept and slope, demonstrating that estimation of $\mathrm{NH}_{3}-\mathrm{N}$ using DFCCS needs further adjustments and that studies investigating this response are warranted. Therefore, even though we observed differences in the estimate of $\beta_{0}$ for some variables, in most cases the magnitude of the response was small, and the biological value of this difference is likely minimum. Most important, the functional responses to different dietary NFC concentrations, EMPS, and NDF and true CP degradability are overall maintained in DFCCS compared with OST.

\section{ACKNOWLEDGMENTS}

We thank the members of our laboratory for assistance with data interpretation and for providing valuable insights. Authors are also grateful to the Conselho Nacional de Desenvolvimento Científico e Tecnológico 
(CNPq; Brasilia, Brazil) for proving financial support to M. I. Marcondes. The authors have not stated any conflicts of interest.

\section{REFERENCES}

Ahvenjärvi, S., A. Vanhatalo, P. Huhtanen, and T. Varvikko. 2000. Determination of reticulo-rumen and whole-stomach digestion in lactating cows by omasal canal or duodenal sampling. Br. J. Nutr. 83:67-77. https://doi.org/10.1017/S0007114500000106.

Amaral, P. M., L. D. Mariz, P. D. Benedeti, L. G. da Silva, E. M. de Paula, H. F. Monteiro, T. Shenkoru, S. A. Santos, S. R. Poulson, and A. P. Faciola. 2016. Effects of static or oscillating dietary crude protein levels on fermentation dynamics of beef cattle diets using a dual-flow continuous culture system. PLoS One 11:e0169170. https://doi.org/10.1371/journal.pone.0169170.

Bach, A., S. Calsamiglia, and M. D. Stern. 2005. Nitrogen metabolism in the rumen. J. Dairy Sci. 88(Suppl. 1):E9-E21. https://doi.org/ 10.3168/jds.S0022-0302(05)73133-7.

Bach, A., I. K. Yoon, M. D. Stern, H. G. Jung, and H. Chester-Jones. 1999. Effects of type of carbohydrate supplementation to lush pasture on microbial fermentation in continuous culture. J. Dairy Sci. 82:153-160. https://doi.org/10.3168/jds.S0022-0302(99)75219-7.

Bergman, E. N. 1990. Energy contributions of volatile fatty acids from the gastrointestinal tract in various species. Physiol. Rev. 70:567590. https://doi.org/10.1152/physrev.1990.70.2.567.

Brandao, V. L. N., L. G. Silva, E. M. Paula, H. F. Monteiro, X. Dai, A. L. J. Lelis, A. Faccenda, S. R. Poulson, and A. P. Faciola. 2018. Effects of replacing canola meal with solvent-extracted camelina meal on microbial fermentation in a dual-flow continuous culture system. J. Dairy Sci. 101:9028-9040. https://doi.org/10.3168/jds .2018-14826.

Brito, A. F., G. F. Tremblay, H. Lapierre, A. Bertrand, Y. Castonguay, G. Bélanger, R. Michaud, C. Benchaar, D. R. Ouellet, and R. Berthiaume. 2009. Alfalfa cut at sundown and harvested as baleage increases bacterial protein synthesis in late-lactation dairy cows. J. Dairy Sci. 92:1092-1107. https://doi.org/10.3168/jds.2008 $-1469$.

Broderick, G. A., P. Huhtanen, S. Ahvenjärvi, S. M. Reynal, and K. J. Shingfield. 2010. Quantifying ruminal nitrogen metabolism using the omasal sampling technique in cattle - A meta-analysis. J. Dairy Sci. 93:3216-3230. https://doi.org/10.3168/jds.2009-2989.

Calsamiglia, S., A. Ferret, and M. Devant. 2002. Effects of $\mathrm{pH}$ and $\mathrm{pH}$ fluctuations on microbial fermentation and nutrient flow from a dual-flow continuous culture system. J. Dairy Sci. 85:574-579. https://doi.org/10.3168/jds.S0022-0302(02)74111-8.

Coe, M. L., T. G. Nagaraja, Y. D. Sun, N. Wallace, E. G. Towne, K. E. Kemp, and J. P. Hutcheson. 1999. Effect of virginiamycin on ruminal fermentation in cattle during adaptation to a high concentrate diet and during an induced acidosis. J. Anim. Sci. 77:2259-2268. https://doi.org/10.2527/1999.7782259x.

Dai, X., E. M. Paula, A. L. J. Lelis, L. G. Silva, V. L. N. Brandao, H. F. Monteiro, P. Fan, S. R. Poulson, K. C. Jeong, and A. P. Faciola. 2019. Effects of lipopolysaccharide dosing on bacterial community composition and fermentation in a dual-flow continuous culture system. J. Dairy Sci. 102:334-350. https://doi.org/10.3168/jds .2018-14807.

DeFrain, J. M., A. R. Hippen, K. F. Kalscheur, and D. J. Schingoethe. 2004. Feeding lactose increases ruminal butyrate and plasma $\beta$-hydroxybutyrate in lactating dairy cows. J. Dairy Sci. 87:24862494. https://doi.org/10.3168/jds.S0022-0302(04)73373-1.

Esdale, W. J., G. A. Broderick, and L. D. Satter. 1968. Measurement of ruminal volatile fatty acid production from alfalfa hay or corn silage rations using a continuous infusion isotope dilution technique. J. Dairy Sci. 51:1823-1830. https://doi.org/10.3168/jds .S0022-0302(68)87285-6.

Gozho, G. N., M. R. Hobin, and T. Mutsvangwa. 2008. Interactions between barley grain processing and source of supplemental dietary fat on nitrogen metabolism and urea-nitrogen recycling in dairy cows. J. Dairy Sci. 91:247-259. https://doi.org/10.3168/jds .2007-0407.

Hall, M. B., T. D. Nennich, P. H. Doane, and G. E. Brink. 2015. Total volatile fatty acid concentrations are unreliable estimators of treatment effects on ruminal fermentation in vivo. J. Dairy Sci. 98:3988-3999. https://doi.org/10.3168/jds.2014-8854.

Hannah, S. M., M. D. Stern, and F. R. Ehle. 1986. Evaluation of a dual flow continuous culture system for estimating bacterial fermentation in vivo of mixed diets containing various soya bean products. Anim. Feed Sci. Technol. 16:51-62. https://doi.org/10 .1016/0377-8401(86)90049-0.

Hoover, W. H., B. A. Crooker, and C. J. Sniffen. 1976. Effects of differential solid-liquid removal rates on protozoa numbers in continuous cultures of rumen contents. J. Anim. Sci. 43:528-534. https:// doi.org/10.2527/jas1976.432528x.

Hristov, A. N. N., C. Lee, R. Hristova, P. Huhtanen, and J. L. L. Firkins. 2012. A meta-analysis of variability in continuous-culture ruminal fermentation and digestibility data. J. Dairy Sci. 95:52995307. https://doi.org/10.3168/jds.2012-5533.

Huhtanen, P., P. G. Brotz, and L. D. Satter. 1997. Omasal sampling technique for assessing fermentative digestion in the forestomach of dairy cows. J. Anim. Sci. 75:1380-1392. https://doi.org/10 $.2527 / 1997.7551380 x$.

Lapierre, H., and G. E. Lobley. 2001. Nitrogen recycling in the ruminant: A review. J. Dairy Sci. 84:E223-E236. https://doi.org/10 .3168/jds.S0022-0302(01)70222-6.

Mansfield, H. R., M. I. Endres, and M. D. Stern. 1995. Comparison of microbial fermentation in the rumen of dairy cows and dual flow continuous culture. Anim. Feed Sci. Technol. 55:47-66. https://doi .org/10.1016/0377-8401(95)98202-8.

Marini, J. C., and M. E. Van Amburgh. 2003. Nitrogen metabolism and recycling in Holstein heifers. J. Anim. Sci. 81:545-552. https:/ /doi.org/10.2527/2003.812545x.

Marounek, M., K. Fliegrova, and S. Bartos. 1989. Metabolism and some characteristics of ruminal strains of Megasphaera elsdenii. Appl. Environ. Microbiol. 55:1570-1573.

Mertens, D. R. 1977. Dietary fiber components: Relationship to the rate and extent of ruminal digestion. Fed. Proc. 36:187-192.

Nagaraja, T. G., and E. C. Titgemeyer. 2007. Ruminal acidosis in beef cattle: The current microbiological and nutritional outlook. J. Dairy Sci. 90:E17-E38. https://doi.org/10.3168/jds.2006-478.

NRC. 2001. Nutrient Requirements of Dairy Cattle. 7th rev. ed. National Academies Press, Washington, DC.

Oba, M., and M. S. Allen. 2003. Effects of diet fermentability on efficiency of microbial nitrogen production in lactating dairy cows. J. Dairy Sci. 86:195-207. https://doi.org/10.3168/jds.S0022 $-0302(03) 73600-5$.

Offner, A., and D. Sauvant. 2004. Prediction of in vivo starch digestion in cattle from in situ data. Anim. Feed Sci. Technol. 111:41-56. https://doi.org/10.1016/S0377-8401(03)00216-5.

Owens, D., M. McGee, T. Boland, and P. O'Kiely. 2008. Intake, rumen fermentation and nutrient flow to the omasum in beef cattle fed grass silage fortified with sucrose and/or supplemented with concentrate. Anim. Feed Sci. Technol. 144:23-43. https://doi.org/ 10.1016/j.anifeedsci.2007.09.032.

Reynal, S. M., G. A. Broderick, S. Ahvenjärvi, and P. Huhtanen. 2003. Effect of feeding protein supplements of differing degradability on omasal flow of microbial and undegraded protein. J. Dairy Sci. 86:1292-1305. https://doi.org/10.3168/jds.S0022-0302(03)73713 $-8$.

Roman-Garcia, Y., R. R. White, and J. L. Firkins. 2016. Meta-analysis of postruminal microbial nitrogen flows in dairy cattle. I. Derivation of equations. J. Dairy Sci. 99:7918-7931. https://doi.org/10 $.3168 /$ jds.2015-10661.

Russell, J. B., J. D. O'Connor, D. G. Fox, P. J. Van Soest, and C. J. Sniffen. 1992. A net carbohydrate and protein system for evaluating cattle diets: I. Ruminal fermentation. J. Anim. Sci. 70:35513561. https://doi.org/10.2527/1992.70113551x.

Satter, L. D., and W. J. Esdale. 1968. In vitro lactate metabolism by ruminal ingesta. Appl. Microbiol. 16:680-688. 
Satter, L. D., and L. L. Slyter. 1974. Effect of ammonia concentration on rumen microbial protein production in vitro. Br. J. Nutr. 32:199-208. https://doi.org/10.1079/bjn19740073.

Sauvant, D., P. Schmidely, J. J. Daudin, and N. R. St-Pierre. 2008. Meta-analyses of experimental data in animal nutrition. Animal 2:1203-1214. https://doi.org/10.1017/S1751731108002280.

Schwab, E. C., C. G. Schwab, R. D. Shaver, C. L. Girard, D. E. Putnam, and N. L. Whitehouse. 2006. Dietary forage and nonfiber carbohydrate contents influence B-vitamin intake, duodenal flow, and apparent ruminal synthesis in lactating dairy cows. J. Dairy Sci. 89:174-187. https://doi.org/10.3168/jds.S0022-0302(06)72082 $-3$.

Sniffen, C. J., J. D. O'Connor, P. J. Van Soest, D. G. Fox, and J. B. Russell. 1992. A net carbohydrate and protein system for evaluating cattle diets: II. Carbohydrate and protein availability. J. Anim. Sci. 70:3562-3577. https://doi.org/10.2527/1992.70113562x.

St-Pierre, N. R. 2001. Invited review: Integrating quantitative findings from multiple studies using mixed model methodology. J. Dairy Sci. 84:741-755. https://doi.org/10.3168/jds.S0022-0302(01)74530 -4 .

Steel, R. G. D., J. H. Torrie, and D. A. Dickey. 1997. Principles and Procedures of Statistics: A Biometrical Approach. 3rd ed. McGraw-Hill, New York, NY.

Sterk, A., B. Vlaeminck, A. M. van Vuuren, W. H. Hendriks, and J. Dijkstra. 2012. Effects of feeding different linseed sources on oma- sal fatty acid flows and fatty acid profiles of plasma and milk fat in lactating dairy cows. J. Dairy Sci. 95:3149-3165. https://doi.org/ $10.3168 /$ jds.2011-4474.

Tuori, M., M. Rinne, and A. Vanhatalo. 2008. Omasal sampling technique in estimation of the site and extent of mineral absorption in dairy cows fed rapeseed and soybean expellers. Agric. Food Sci. 15:219-234. https://doi.org/10.2137/145960606779216254.

Vallimont, J. E., F. Bargo, T. W. Cassidy, N. D. Luchini, G. A. Broderick, and G. A. Varga. 2004. Effects of replacing dietary starch with sucrose on ruminal fermentation and nitrogen metabolism in continuous culture. J. Dairy Sci. 87:4221-4229. https://doi.org/10 .3168/jds.S0022-0302(04)73567-5.

Weller, R. A., and A. F. Pilgrim. 1974. Passage of protozoa and volatile fatty acids from the rumen of the sheep and from a continuous in vitro fermentation system. Br. J. Nutr. 32:341-351. https://doi .org/10.1079/BJN19740087.

\section{ORCIDS}

V. L. N. Brandao @ 1 https://orcid.org/0000-0002-7413-9676

M. I. Marcondes () https://orcid.org/0000-0003-4843-2809

A. P. Faciola (ㄴ) https://orcid.org/0000-0003-0935-6233 